\title{
Teaching Learning Methodology in Times of COVID-19 Pandemic: A Case Study
}

D, Ghildyal (Divya Ghildyal) ${ }^{1}$, S. Kumar (Santhosh Kumar M B)², S. Yadav (Sharda Yadav) ${ }^{3}$, R. Khare (Rishabh Khare) $)^{3}$

${ }^{1}$ Assistant Professor, Dept. of Physics, JSS Academy of Technical Education, Noida. IN.

${ }^{2}$ Assistant Professor, Dept. of Civil Engineering, JSS Academy of Technical Education, Noida. IN.

${ }^{3}$ Teacher at Slum Swaraj Foundation (NGO). IN.

\section{E-mail address:}

divyaghildyal@gmail.com

\section{Reprint address:}

Divya Ghildyal

Dept. of Physics

JSS Academy of Technical Education

Noida

India

Source: Clinical Social Work and Health Intervention

Volume: 12

Issue: 4

Pages: $85-97$

Cited references: 22

\section{Reviewers:}

Daniel J. West

University of Scranton, Department of Health Administration and Human Resources, USA

Steve Szydlowski

University of Scranton school of education, USA

\section{Keywords:}

Covid 19 Pandemic. Online Learning. Zoom. Virtual Lab. NPTEL.AKTU.

\section{Publisher:}

International Society of Applied Preventive Medicine i-gap

CSWHI 2021; 12(4): 85 - 97; DOI: 10.22359/cswhi_12_4_11 (C) Clinical Social Work and Health Intervention

\section{Abstract:}

The Education system in India underwent a major change due to the sudden lockdown announced by the Government in view of COVID - 19 pandemic. Both teachers and students had to shift to online mode in a very short time period. The present study analysis the positive and negative aspect of this online mode of education and measures adopted by teachers to maintain the flow of education along with attendance. The survey was conducted at JSS Academy of Technical Education, Noida. More than 100 teachers and students participated in the survey conducted. Also experienced faculty came up with suggestions and ideas to improve the online mode of education in view of such pandemic situations. Two teachers who were also 
teaching kids at an NGO school running in the campus premises shared their view on what efforts they took to let education reach the kids at the NGO as digital divide was the main problem there. Such findings will help in designing a future teaching model to cope with pandemic situations and not let education suffer.

\section{Introduction}

The sudden outbreak of Corona Virus almost brought the whole world to a standstill. (Ben $\mathrm{Hu}$ 2021, Aditi Madan 2021). Seeing its rapid spread and scare to human lives WHO(World Health Organization) declared it a global pandemic (Domenico 2020). Sudden closure of schools and colleges forced the Teaching Learning procedures to shift to online mode completely. (Luca Botturi 2020, Kapasia 2020, Owusu 2020). It was a very tough and challenging task for both teachers and students. (Affouneh 2020, Favale 2020, Todorova 2011). As teachers had to impart education so that student's career did not suffer and their whole year was not wasted while student's had to switch over to online mode as no other option was left in such pandemic times. The biggest challenge with teachers was to keep the teaching spirit alive among students especially those with poor financial conditions, since the biggest challenge with these students was if their studies got a break they would be compelled to return back to a family business which included sitting at shops, household works, robbery, etc.

The present study focusses on understanding the problems faced by Teachers and Students during the lockdown as far as online education is concerned.(Agarwal 2016). The over all aim of the study meant to analyze the measure's teachers and students adopted to keep their education running.

From ancient times, Teaching Learning has been an interactive field where in the teacher and student interact in person. This major feature was at drawback with online mode of education which is technology based. But, due to the lockdown it seemed to be the only solution for the system to keep running. (Shivangi Dhawan 2020). Since, online mode of education is the only option in this time of pandemic where the entire world is forced to sit at home (Al-Fraihat 2020, Arinto 2016). With online mode of education relying on the Internet it is the only way to make education reach every corner of the country as students have migrated to their hometowns in view of lockdown. (Cascio 2016). This mode of teaching on a virtual platform has, both the good and bad. (Cidral 2018, Islam 2015). The best part being it allows flexibility of timings, place, format of lecture delivery which could be a recorded one; power point presentation; lecture by national/international speaker, etc. both for the Teacher/Student giving more exposure to the topic, instead of the usual classroom type where students are bound to have a single teacher in class and follow protocols of timing and place. (Andrew 2013). No doubt, few foundations are there like judgement of students performance with an examination system coming on online platform and students giving exams from home sitting in front of their own system, cannot be matched with the traditional way of examinations which were bounded with center; timing; invigilation by examiners; no carrying books or notes to center; etc. But seeing the pandemic situation (Per Engzell 2020) it is the only way out or else students will be at a loss with wastage of their academic year. (Megan Kuhfeld 2020)

\section{The specific objective of the study was}

- To identify, the problems being faced by teachers and students both when going for an online mode of education.

- To identify the tools and techniques for Teaching Learning methodology which were user friendly.

- To identify the syllabus coverage and how much students were able to adapt and how they managed their practical work.

- To suggest methodology for designing future models of education, especially for pandemic times keeping in mind that such lockdowns become a part of lifestyle.

After compiling the survey results and short listing the genuine problems being faced by them, the problems were discussed with experienced teachers of JSS Academy of Technical Education and the present study made an effort 
to find a solution for the same. The future scope of this work will help in planning of Teaching Learning methodology which are suitable for future pandemic situations. Policy makers will benefit with the suggestions given by both teachers and students in the survey for smooth conduct of online classes in times of pandemic.

\section{Study Area}

This study was carried out at JSS (Jagadguru Sri Shivarathreeshwara ) Academy of Technical Education, Noida which is a private engineering college, affiliated to Dr. A.P.J. Abdul Kalam Technical University situated in Sector 62, Noida. Noida, a planned city is located in the Indian state of Uttar Pradesh, district Gautam Budhh Nagar. The Institute has a large student strength of over 3,000 students and more than 200 faculty members. This study can set an example for other Institutes to follow as far as Teaching Learning Methodology is concerned, especially in such a pandemic situation which has arisen because of COVID-19 lockdown (Lokhnath Mishra 2020).

The survey was conducted in the first 2 weeks of August, 2021 when teachers started reporting to campus for their duties and students came in batches either to vacate hostels, issue books from library, get practical files signed or for clearance of any type of doubts from teachers or any other administrative purpose. This is an academic research to estimate the challenges in online mode of education faced by both teachers and students studying or teaching at JSS Academy of Technical Education, Noida when the whole mode of education shifted to online mode in view of lockdown due to COVID - 19 pandemic. The study was conducted, employing a questionnaire prepared using 'Google form'. An aggregate of 200 students and 180 teachers participated in this survey.

The questionnaire consisted of 2 paragraph based questions where both teachers and students were free to write any suggestion or comment (keeping their identity anonymous) as questionnaire did not ask questions of name and email id compulsory. These suggestions which have been given with free mind have been discussed and will pave the way for planning of a future model of education.

The academy switched to an online mode of education completely during the second lockdown when both Teachers and Students had to explore technology options to keep their education process running smoothly. No doubt it gave more time to the Teaching Learning field to experiment with new techniques and ideas for online mode of education. So many virtual platforms came up, all of a sudden demand for smartphones, laptops, Internet connectivity, microphones, speakers, etc. came up (T. Muthuprasad, 2021). The technology market no doubt got a boom in this time of pandemic when other fields like tourism, travelling, eating outlets had major setbacks due to lockdown.

(Eileen Bridges2017).

\section{Methodology}

Two 'Google Forms' consisting of questions relating to challenges, strengths, weaknesses , technology, time to switch to online mode of education, etc. was created after discussion with experienced faculty members of the institute and literature survey. Two Google forms were circulated one for teachers and one for students via email and What's Up Groups and Google Classroom of their respective classes and other social networking sites. Gentle reminders to teachers were given via email after one week in case any of them were pending. Students were reminded also after a week's time via Google Classroom, email and What's Up Groups created for every branch and section. The students were the one's pursuing B.Tech (in any branch) belonging to the undergraduate stream and telephonic conversations with students who were coming in the NGO classes run in the Academy (before lockdown) for the children from poor family background.

The questionnaire was created in English. Methodology for this study is depicted in Figure

1. The details of the questionnaire and the response data obtained are tabulated in Table 1. 
Figure 1 Methodology Flow Chart

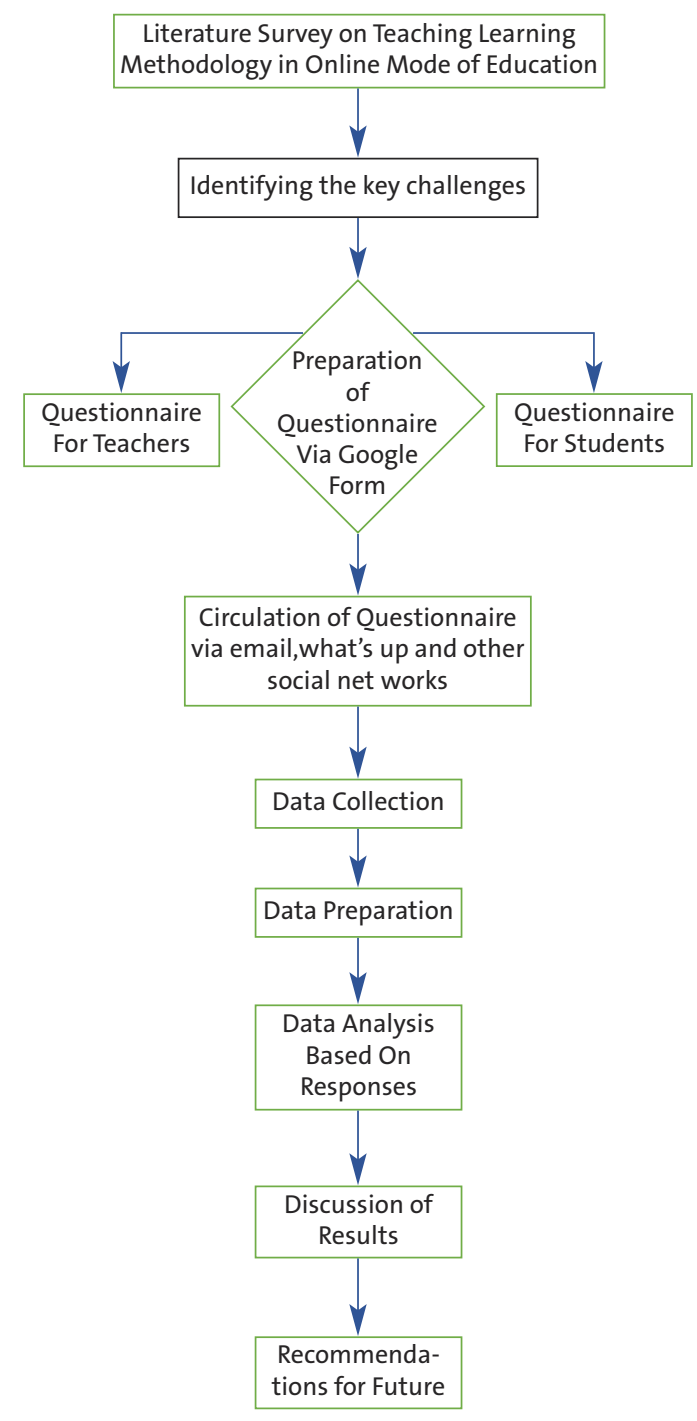

Both the Google forms consisted of 22 questions - 20 multiple choice questions and 2 paragraph based to help identify measures to be taken to improve online education in schools and NGO run by social workers. Each multiple choice question had an option of "other" so that the teacher or student could freely add their option in case missing. A Google form titled "Questionnaire For Teachers" with 20 Multiple Choice Questions and 2 paragraph based were circulated in JSS Academy of Technical Education, Noida (India). Questions 1 \& 2 which asked name and email were not kept compulsory in order to pro- tect privacy and let one answer the questions with free mind, especially students without fear of getting noticed. All the rest of the questions from Question 3 till question 20 (MCQ) were kept compulsory in order to identify the strengths, weaknesses and future aspects of online mode of education for both teachers and students. A $3^{\text {rd }}$ question was of age group starting from 26 years till 60 plus, as many teachers in NGO are the younger ones between 20 to 30 years of age group. Question 4 was based on years of teaching experience, this would give a more clear picture of how useful experience is in picking up online mode of education. Question 5 identified the category of students being taught by that specific teacher i.e. whether undergraduate (pursuing B.Tech), post graduate (pursuing MTech or $\mathrm{PhD}$ ) or the ones being taught in NGO run in the institute premises. This will help in understanding the difference in efforts made by teachers when category is concerned. Question 6 surveys where teachers are being asked to identify the students on the basis of their family income will help in giving an idea to the teacher that to what level the student can afford technology for online classes, categories given here were lower income, lower middle, upper middle and high. With online education, it was felt necessary to know whether the teacher is getting a separate place to conduct his/her online classes as teacher has to interact with a large number of students and usually as per practice they raise their voice while delivering lectures or solving quires of students, in personal room a teacher freedom to interact with students without disturbing their family members, hence in, Question 6 asks whether the teacher has a separate room to deliver his /her lectures. Question 7 is the most important question, where the teacher has been asked what mode he/she is using while delivering lectures all possible options have been included for same. Since, teachers were given very short notice for start of online classes, Question 8 gave them a chance to tell how much time they took in switching over from chalk mode to online mode and balancing their work and family life together an analysis of this question will help the institute in deciding in future how much time should the teachers be given to prepare for online mode and come out with their best for the students. 
Many teachers in the beginning were in a dilemma over whether they would be able to switch over to online mode or not, especially the ones who were not very technology friendly, hence the next question gives them a chance to let know what technology problem they suffered most, so that in future some solution can be found for same or the teachers be updated about it through a webinar or talk. One question each on weakness and positive aspect of online education was asked with options which are general with teachers were given.

Since, there are so many platforms of delivering lectures next question asked was, which specific platform the teacher found convenient as per his/her situation. Major online platforms were mentioned in the options. Since, the second wave of the COVID pandemic was a very severe one with almost every 3rd house having a tragedy, it was very necessary for a teacher to keep the human aspect also while teaching, hence question focusses on the human aspect given while teaching students, so that the pandemic does not have a even greater impact on their studies and they at least attend their classes. The next 3 questions, focused on the methodology aspect of teaching. In Question 15, the teacher has been questioned about the methodology adopted for lab/field work especially data handling and in question sixteen an update is taken from teacher regarding the technique they are adopting to increase or maintain a good strength of attendance in their class, this is very important aspect as many previous surveys have reported the problem of short attendance in online mode of education. The correct answer to this problem will help teachers solve the problem of short attendance.

Since, a teacher has to prepare his/her lecture beforehand, especially when online mode is considered it is necessary to get an idea of the time taken by the teacher on a daily basis for preparing his/her next lecture as many teachers especially the ones teaching small kids in NGOs have to prepare colorful, animated lectures to attract the attention of small children an idea of its time consumption is very important. Question 19 takes a general feedback from teachers to what type of lecture kept the students engaged, this question can truly only be answered by those teachers who took their classes regularly and monitored the attendance of the students. Last multiple choice question is about stating the biggest disadvantage of online education, though in this time of pandemic online education is the only solution, but still an answer to this question can help improve the disadvantage. From Question 3 to 20 (MCQ) all questions were given the option "other" so that, in case anyone has any other option which has not been mentioned then they can state it. The last two Question $21 \& 22$ have been kept paragraph based and NOT compulsory so that views can be expressed freely. Question 21, gives the respondent freedom to give suggestions to improve the online mode of education, and lastly 22 another paragraph based question openly asks for any type of feedback.

\section{Questionnaire for Students}

Based on similar pattern as that of teachers, a questionnaire for students was prepared with few variations. The age group in case of students was lowered and range was kept between 5 to 25 years. Lower age group was meant for NGO kids, while the ones above 18 for undergraduate and postgraduate students was kept. Minor change was done in Question 18, wherein students were asked about how much time it took them to solve the quizzes and assignments they were receiving. Rest of the pattern was similar as that of teacher's questionnaire.

\section{Table1}

\begin{tabular}{|l|c|c|}
\hline $\begin{array}{c}\text { Parameter } \\
\text { under } \\
\text { Study }\end{array}$ & $\begin{array}{c}\text { Teacher's } \\
\text { Responses } \\
(\%)\end{array}$ & $\begin{array}{c}\text { Student's } \\
\text { Responses } \\
\text { (\%) }\end{array}$ \\
\hline Age Group & $0 \%$ & $44 \%$ \\
\hline $\begin{array}{l}\text { Above } \\
15 \text { years }\end{array}$ & $0 \%$ & $56 \%$ \\
\hline $\begin{array}{l}\text { Above } \\
20 \text { years }\end{array}$ & - & $0 \%$ \\
\hline $\begin{array}{l}\text { Above } \\
25 \text { years }\end{array}$ & $20 \%$ & - \\
\hline $\begin{array}{l}\text { Between } \\
26-31 \text { years }\end{array}$ & $44 \%$ & - \\
\hline $\begin{array}{l}\text { Between } \\
32-38 \text { years }\end{array}$ & $26 \%$ & - \\
\hline $\begin{array}{l}\text { Above } \\
40 \text { years }\end{array}$ & $10 \%$ & - \\
\hline $\begin{array}{l}\text { Above } \\
50 \text { years }\end{array}$ & & \\
\hline
\end{tabular}




\begin{tabular}{|c|c|c|}
\hline \multicolumn{3}{|l|}{ Category } \\
\hline Undergraduate & $82 \%$ & $83 \%$ \\
\hline Postgraduate & $12 \%$ & $9 \%$ \\
\hline NGO & $6 \%$ & $8 \%$ \\
\hline \multicolumn{3}{|l|}{ Gender Distribution } \\
\hline Female & $48 \%$ & $28 \%$ \\
\hline Male & $52 \%$ & $72 \%$ \\
\hline \multicolumn{3}{|l|}{ Family Income Status } \\
\hline Lower Income & $6 \%$ & $18 \%$ \\
\hline Lower Middle & $42 \%$ & $39 \%$ \\
\hline Upper Middle & $50 \%$ & $43 \%$ \\
\hline High & $2 \%$ & - \\
\hline \multicolumn{3}{|l|}{ Separate Room for Studies } \\
\hline yes & $76 \%$ & $46 \%$ \\
\hline no & $24 \%$ & $54 \%$ \\
\hline \multicolumn{3}{|l|}{$\begin{array}{l}\text { Mode of Attending } \\
\text { Online Classes }\end{array}$} \\
\hline Desktop & $4 \%$ & $2 \%$ \\
\hline Laptop & $94 \%$ & $50 \%$ \\
\hline Tablet & - & $4 \%$ \\
\hline Smart Phone & $2 \%$ & $44 \%$ \\
\hline \multicolumn{3}{|l|}{$\begin{array}{l}\text { Time Taken In Balancing } \\
\text { Home/Work }\end{array}$} \\
\hline 1 week & $60 \%$ & $17 \%$ \\
\hline 2 week & $22 \%$ & $11 \%$ \\
\hline 3 weeks & $6 \%$ & $15 \%$ \\
\hline More than 3 weeks & $12 \%$ & $57 \%$ \\
\hline \multicolumn{3}{|l|}{ Technology Drawbacks } \\
\hline Downloading errors & $12 \%$ & $6 \%$ \\
\hline Issues with installations & $14 \%$ & $15 \%$ \\
\hline Log in problems & $16 \%$ & $20 \%$ \\
\hline $\begin{array}{l}\text { Problems with } \\
\text { audio/video }\end{array}$ & $48 \%$ & $59 \%$ \\
\hline others & $10 \%$ & - \\
\hline \multicolumn{3}{|l|}{\begin{tabular}{|l} 
Strength with \\
Online Teaching \\
\end{tabular}} \\
\hline Flexibility of location & $50 \%$ & $48 \%$ \\
\hline Flexibility of time & $24 \%$ & $28 \%$ \\
\hline $\begin{array}{l}\text { Interaction with larger } \\
\text { groups of students }\end{array}$ & $16 \%$ & $4 \%$ \\
\hline Saves cost & $4 \%$ & $20 \%$ \\
\hline others & $6 \%$ & - \\
\hline \multicolumn{3}{|l|}{$\begin{array}{l}\text { Weakness of } \\
\text { Online Education }\end{array}$} \\
\hline Time Management & $8 \%$ & $11 \%$ \\
\hline Technical Difficulty & $18 \%$ & $24 \%$ \\
\hline $\begin{array}{l}\text { Distractions from } \\
\text { home front }\end{array}$ & $8 \%$ & $30 \%$ \\
\hline $\begin{array}{l}\text { Face to face interaction } \\
\text { with whole class missing }\end{array}$ & $64 \%$ & $35 \%$ \\
\hline others & $8 \%$ & \\
\hline
\end{tabular}

\begin{tabular}{|c|c|c|}
\hline $\begin{array}{l}\text { Positive Aspect of } \\
\text { Online Education }\end{array}$ & & \\
\hline $\begin{array}{l}\text { Designing flexible } \\
\text { programs }\end{array}$ & $14 \%$ & $8 \%$ \\
\hline $\begin{array}{l}\text { Scope for digital } \\
\text { development }\end{array}$ & $34 \%$ & $24 \%$ \\
\hline $\begin{array}{l}\text { Various formats } \\
\text { of lectures }\end{array}$ & $32 \%$ & $13 \%$ \\
\hline $\begin{array}{l}\text { Saves time of travelling } \\
\text { to college /school }\end{array}$ & $12 \%$ & $48 \%$ \\
\hline \begin{tabular}{|l|} 
others \\
Most User Friendly \\
Platform
\end{tabular} & $8 \%$ & $7 \%$ \\
\hline Zoom & $78 \%$ & $72 \%$ \\
\hline Microsoft teams & $8 \%$ & $4 \%$ \\
\hline Google meet & $12 \%$ & $24 \%$ \\
\hline others & $2 \%$ & - \\
\hline $\begin{array}{l}\text { Efforts To Maintain } \\
\text { Human Touch to Lectures }\end{array}$ & & \\
\hline $\begin{array}{l}\text { Motivation given by } \\
\text { teachers from time to time }\end{array}$ & $52 \%$ & $41 \%$ \\
\hline $\begin{array}{l}\text { Free interaction with } \\
\text { teacher on personal issue }\end{array}$ & $10 \%$ & $22 \%$ \\
\hline $\begin{array}{l}\text { Flexibility in } \\
\text { timings of class }\end{array}$ & - & $9 \%$ \\
\hline $\begin{array}{l}\text { Study material provided } \\
\text { separately }\end{array}$ & $24 \%$ & $28 \%$ \\
\hline others & $14 \%$ & - \\
\hline \begin{tabular}{|l|} 
Percentage of \\
Curriculum Covered
\end{tabular} & & \\
\hline $100 \%$ & $58 \%$ & $35 \%$ \\
\hline Between $80-100 \%$ & $30 \%$ & $33 \%$ \\
\hline Between 60\%-80\% & $12 \%$ & $20 \%$ \\
\hline Below 50\% & - & $12 \%$ \\
\hline $\begin{array}{l}\text { Methodology Adopted } \\
\text { for Lab/field work }\end{array}$ & & \\
\hline $\begin{array}{l}\text { Used data of secondary } \\
\text { source }\end{array}$ & $12 \%$ & $15 \%$ \\
\hline $\begin{array}{l}\text { You tube videos available } \\
\text { for experiments }\end{array}$ & $24 \%$ & $48 \%$ \\
\hline Virtual lab links used & $56 \%$ & $24 \%$ \\
\hline $\begin{array}{l}\text { Only theoretical aspect } \\
\text { of experiment updated }\end{array}$ & $6 \%$ & $13 \%$ \\
\hline $\begin{array}{l}\text { Number of Hours Spent } \\
\text { Daily in Preparing/ } \\
\text { Solving quizzes/ } \\
\text { Google forms etc. }\end{array}$ & & \\
\hline $1-2$ hours & $44 \%$ & $46 \%$ \\
\hline 3-4 hours & $46 \%$ & $22 \%$ \\
\hline 4-5 hours & $8 \%$ & $4 \%$ \\
\hline Less than 1 hour & $2 \%$ & $28 \%$ \\
\hline
\end{tabular}




\begin{tabular}{|l|c|c|}
\hline $\begin{array}{l}\text { Project/Assignment } \\
\text { Lecture Most Engaging } \\
\text { for Class }\end{array}$ & & \\
\hline Self recorded video lectures & $24 \%$ & $19 \%$ \\
\hline You tube videos & $14 \%$ & $20 \%$ \\
\hline NPTEL lectures & $18 \%$ & $11 \%$ \\
\hline $\begin{array}{l}\text { Lectures from } \\
\text { international speakers }\end{array}$ & $6 \%$ & $4 \%$ \\
\hline $\begin{array}{l}\text { Assignments given via } \\
\text { Google forms }\end{array}$ & $26 \%$ & $35 \%$ \\
\hline others & $12 \%$ & $11 \%$ \\
\hline $\begin{array}{l}\text { Disadvantage With } \\
\text { Online Mode of Teaching }\end{array}$ & $40 \%$ & $36 \%$ \\
\hline Created a sense of isolation & $4 \%$ \\
\hline $\begin{array}{l}\text { Missed face to face } \\
\text { direct interaction }\end{array}$ & $10 \%$ & $8 \%$ \\
\hline $\begin{array}{l}\text { Fair judgement of } \\
\text { students performance } \\
\text { not possible }\end{array}$ & $60 \%$ & $13 \%$ \\
\hline \begin{tabular}{l} 
Technical Failure \\
\hline $\begin{array}{l}\text { not possible to move to } \\
\text { digital content } \\
\text { (by Students) }\end{array}$
\end{tabular} & $30 \%$ \\
\hline
\end{tabular}

Once the deadline of two weeks was over, the response link was closed and Google form of both teachers and students was downloaded as Excel. A total of 120 responses of teachers were there followed with 149 responses of students. After checking the responses invalid and incomplete entries were excluded and 100 entries of teachers and 108 entries of students were finalized for further studies. In addition to this, 2 Teaching Learning students of NGO were spoken on phone as they were not coming to campus and showed inability in filling the Google form, along with suggestions of experienced and senior faculty members taken for improvement of the Teaching Learning Methodology in lockdown.

\section{Results and Discussions}

A total of $52 \%$ male and $48 \%$ female teachers; $28 \%$ female and $72 \%$ male students. The survey further took a look at the age groups of teachers and students as the academy comprises of teachers of all age groups. $10 \%$ of teachers were in the age group above 50, giving the survey a chance to take advantage of the experience of these senior faculty members which can help the younger teachers. $26 \%$ of teachers were in the age group of above 40 ; highest percentage $44 \%$

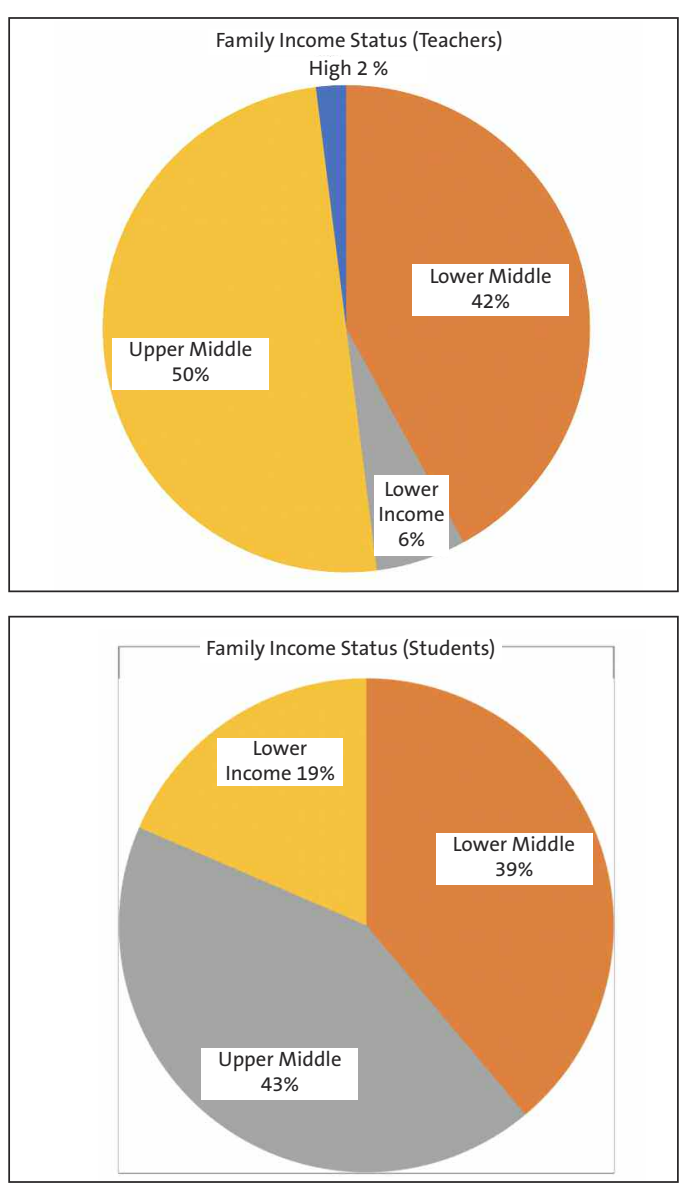

of middle age group teachers 32 to 38 years of age; while $20 \%$ between the age of 26 to 31 years. Student age group comprised of majority strength of $56 \%$ above 20 years the ones pursuing B.Tech (Bachelor of Technology) from the institute and belonging to the 3rd year, 4th year or post graduate programs; $44 \%$ above 15 years of age comprised of B.Tech 1st year students and NGO kids. The family income status Figure 2, was also looked into before starting the survey because online mode requires electronic gadgets, which generally are not possible for students to purchase if they come from very poor family backgrounds, especially the NGO kids. The survey showed that majority strength of teachers belonged to the upper middle income group 50\% which made it possible for them to afford Laptops, Stable net connection, smart phones, writing pads etc. for smooth conduct of classes during lockdown. $42 \%$ belonged to the lower middle income group; $6 \%$ belonged to the lower income; $2 \%$ to the high income group. 
With students, also a similar result was obtained where $43 \%$ belonged to the upper middle class; $39 \%$ in lower middle class; $18 \%$ in the lower income group which were the NGO kids.

Going into depth of survey it was asked whether both students and teachers have a separate room to study: $76 \%$ of teachers had a separate room to take online classes; $24 \%$ did not. While $54 \%$ of students did not have a separate room to study; only $46 \%$ had one. This could be attributed to the fact that since teachers are earning and in higher age group compared to students and probably residing in their own residences, they have a separate room, but students must be sharing their study room with their siblings or other family members.

\section{Figure 2 Author Survey Family Income Status}

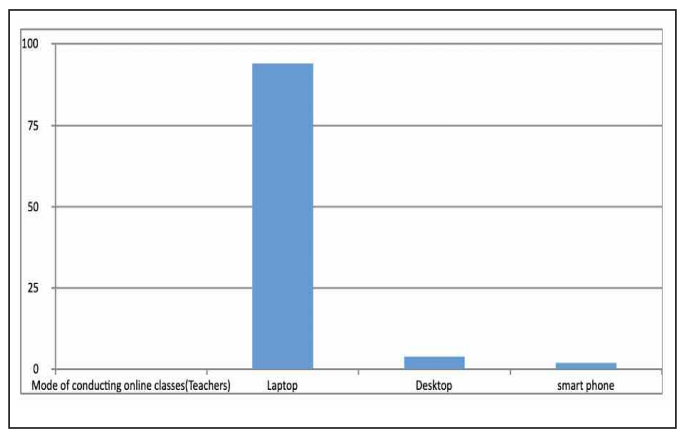

When questioned about the mode of conduct of online classes, $94 \%$ of teachers used Laptop; $4 \%$ using desktop; $2 \%$ using smartphone. With students small variation in results was seen with $50 \%$ possessing a Laptop; followed by $44 \%$ with smart phones; $4 \%$ had Tablet; $2 \%$ a desktop. Higher ratio of smart phones with students could be because of sudden lockdown announcement by Government they

Figure 3 Mode of Conducting Classes

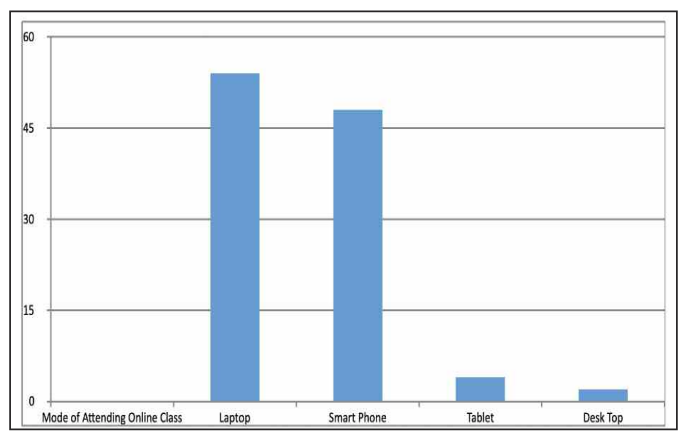

could not possibly afford a Laptop in such a small time, hence keeping the family budget in mind they compromised with a smartphone. Giving an option to teachers to choose mode of lectures which are easily accessible on smart phones and quizzes /assignments etc be designed such that students can solve them on smartphones.

Next question asked was how much time both teachers and students took in balancing studies from home. It was found that $60 \%$ of the teachers took less than a

\section{Figure 4 Time Taken to Switch Over}

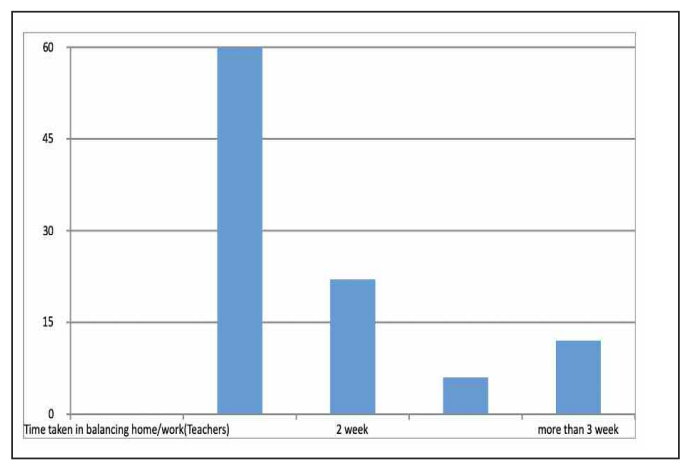

weeks time to settle down: $22 \%$ took 2 weeks may be they arranged the Wi- fi or Network for smooth conduct of the classes; while $12 \%$ took more than weeks in arranging the same; $6 \%$ took three weeks.

The survey results of students showed that it took them longer time compared to teachers in balancing the attending of online classes: $57 \%$ took more than 3 weeks; reason could be with sudden announcement of lockdown these students had to vacate the hostels and rooms taken on rent and travel to their home town which was time taking; followed by $17 \%$ students who took less than a week because of being local candidates and availability of stable net connection along with laptop or smart phone at home; $15 \%$ took 3 weeks; $11 \%$ took 2 weeks. 


\section{Figure 5 Drawback of Online Education}

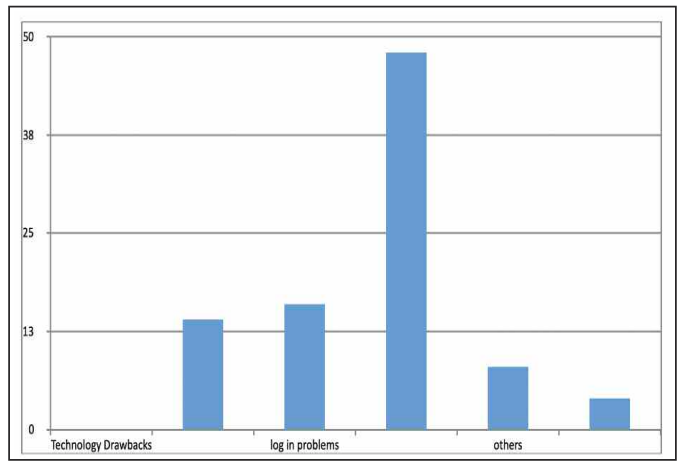

Figure 6 Drawback of Online Education Students Teachers

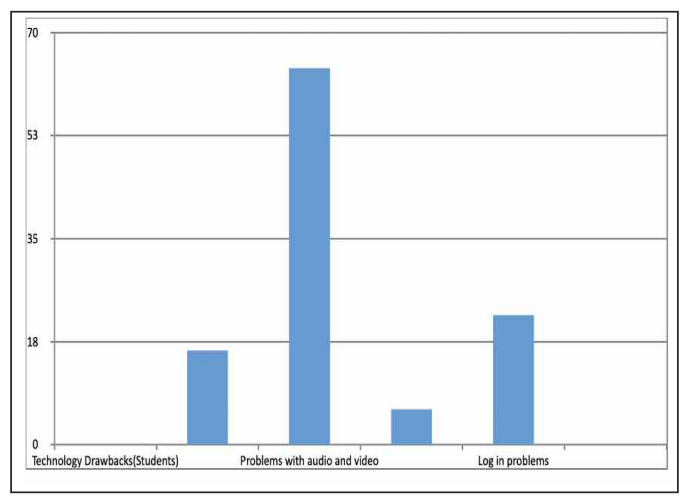

As is clear from the bar charts Figure 5 and 6 , both teachers and students suffered problem of audio and video during online classes which seems to be their major technology drawback. Followed by other issues of log in problems: $16 \%$, had issues with installations; $14 \%$ with teachers; followed by $12 \%$ downloading problems: with students $20 \%$ had log in problems; followed by $15 \%$ with issues of installations and $6 \%$ with downloading errors.

Figure 7 Strength of Online Education (Teachers)

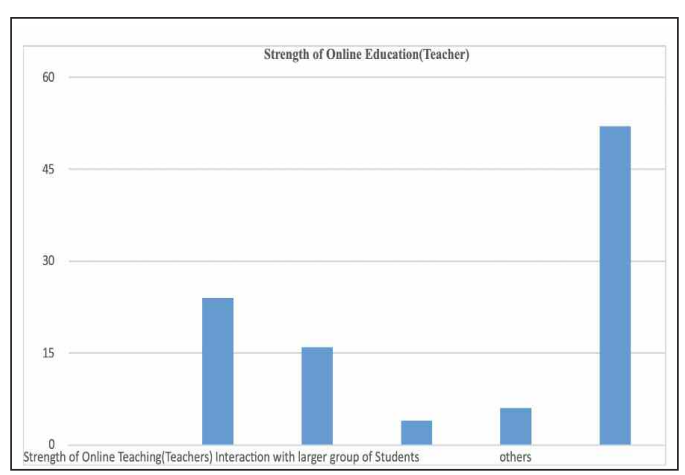

Figure 8 (Strength of Online Education Students)

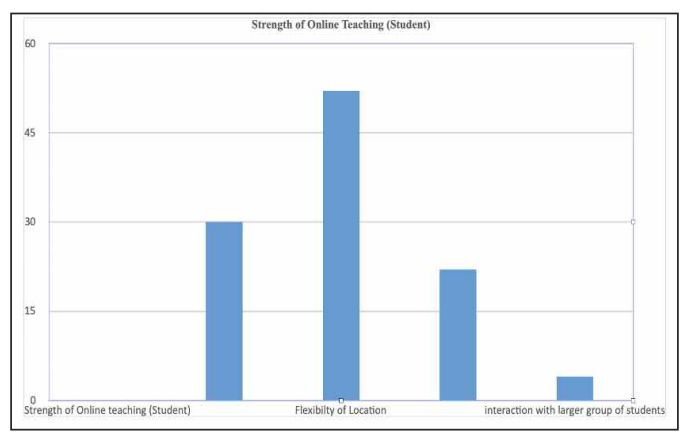

When questioned about the strength of online teaching both teacher and student came up with maximum response for flexibility of location; both Figure 7 and 8 gave a $50 \%$ positive response for the same followed by flexibility of time with $24 \%$ teachers agreeing to it and $28 \%$ students. For the option of saving cost with online mode of teaching students positive response was more than $20 \%$ compared to teachers who gave only a $4 \%$ response to the option; this could be attributed to the fact that teachers are earning and finance is not a constraint for them, but for students finance seems a major constraint when switching over to online mode of education.

On weakness of online teaching both teachers and students gave a thumbs up for missing face to face interaction with $64 \%$ teachers and $35 \%$ students agreeing to this point; followed by $18 \%$ of teachers suffering technical difficulties and $8 \%$ distraction from home front. The results varied for students when distraction from home front was considered as $30 \%$ students suffered the distraction from their home front, maybe because they did not have a separate room to study.

When questioned about the positive aspect of online education $34 \%$ of teachers agreed to the fact that it had scope for digital development, followed by $32 \%$ agreeing to ease of various formats to deliver lectures. But when the question was raised to students their responses varied, with a maximum number $48 \%$ agreeing that it saved time of traveling to school college; followed by $24 \%$ agreeing to the scope of digital development; $13 \%$ agreeing to various formats of lectures. It seems, once again the cost factors play a major role in judging the positive side of online education.

For the question of most user friendly platform for online mode of education it seems Zoom 
emerged the winner with both teachers and students giving it the highest vote: teachers voted $78 \%$ for Zoom, followed by $12 \%$ for Google Meet, and $8 \%$ for Microsoft Teams. While students gave a $72 \%$ response for Zoom, 24\% for Google Meet, and 4\% for Microsoft Teams.

Zoom platform (Figure 9) seemed to be the most popular among both teachers and students. Zoom platform found its popularity because of ease of application; availability of app on smart phone; easy creation of meeting link; user friendly mode of operation.

\section{Figure 9 Most User Friendly Platform}

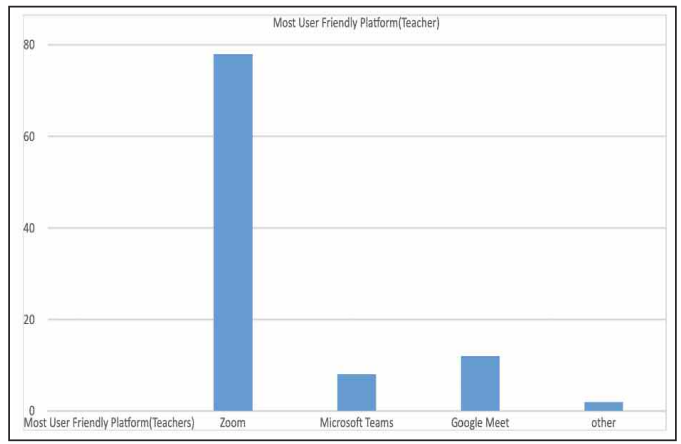

With online mode of education the only option in the time of pandemic caused due to COVID-19 where many people lost their lives especially in the $2^{\text {nd }}$ wave with every 2 nd house having a tragedy due to the deadly virus it was very challenging to maintain a human touch to education while $52 \%$ of teachers agreed they kept motivating their students emotionally in between lectures on daily basis so that students do not lose touch to studies and land in depression; $10 \%$ of teachers called up students after class to speak to them personally and motivated them not to lose hope. Similar responses were obtained from students where $41 \%$ agreed to getting motivation from their teachers in this time of pandemic; $28 \%$ agreed to extra efforts made by teachers in providing notes and other class material which they missed due to tragedy; $22 \%$ agreed to the extra time given by teachers.

On the syllabus front, $58 \%$ of teachers managed to complete their prescribed curriculum timely; while $30 \%$ managed between $80 \%$ to $100 \% ; 12 \%$ between $60 \%$ to $80 \%$; these were the ones teaching the NGO kids where in the students coming in classes run by the NGO group failed to a great extent in switching over to new technology because of which their basic syllabus suffered.

As far as the students were concerned $35 \%$ only managed to study their full syllabus; $33 \%$ between $80 \%$ to $100 \%$; followed by $21 \%$ between $60 \%$ and $80 \%$; followed by $12 \%$ of students who managed to complete below $50 \%$ of their syllabus.

The next question was the number of hours spent on a daily basis by teachers in preparing their lectures for online mode, Google forms, quizzes etc. which they were giving students on a daily basis, $46 \%$ teachers on an average took 3 to 4 hours; followed by $44 \%$ who took between 1 to 2 hours; $8 \%$ took 4 to 5 hours maybe because of unstable internet connectivity; $2 \%$ took less than 1 hour because of all available resources. While $46 \%$ of the students managed to solve their quizzes, etc. in 1 to 2 hours; followed by $28 \%$ who took less than 1 hour; $2 \% 3$ to 4 hours; only $4 \%$ took 4 to 5 hours maybe they must be engaged in house work or having less net connectivity.

Since, almost all courses required lab work teachers and students were asked about the methodology they adopted for it. Figure 10 \& 11: $56 \%$ of teachers agreed to using virtual lab links provided by AKTU (Abdul Kalam Technical University) on their website; $24 \%$ agreeing to showing youtube video links available on site; $12 \%$ used data of a secondary source; $2 \%$ updated students with theoretical aspects of laboratory work. Student analysis showed that $48 \%$ relied on available youtube videos; $24 \%$ used virtual lab links provided by AKTU; $15 \%$ used data of secondary source; $13 \%$ updated themselves with the theoretical aspect of the experiments.

\section{Figure 10 Methodology Adopted for Lab}

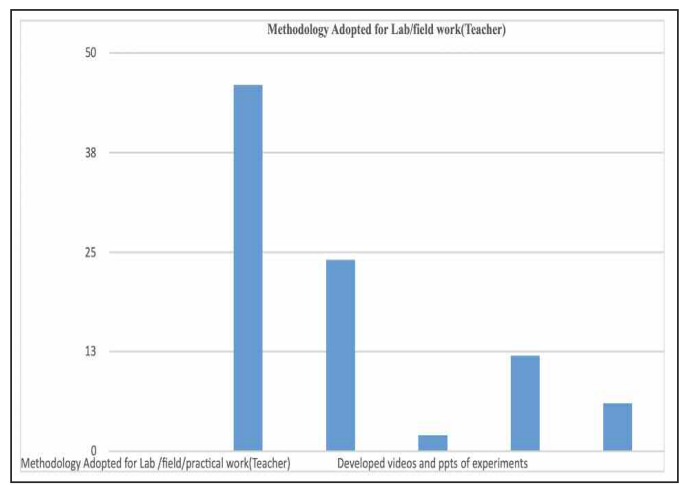




\section{Figure 11 Methodology Adopted For Lab} (Student)

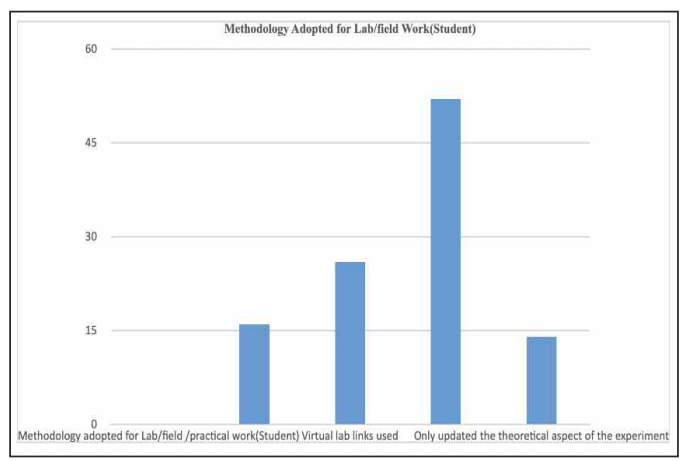

When questioned about assignment found most engaging for class both teachers and students voted maximum for Google forms prepared on daily basis followed by recorded videos of teachers, youtube videos and because of easy contact with experts NPTEL lectures also found space in students survey. Once again when questioned about the biggest disadvantage of online mode of education both teachers and students agreed to missing direct face to face interaction followed by technical failure and creation of a sense of isolation.

\section{Figure 12 Methodology Adopted by Teachers To Increase Attendance}

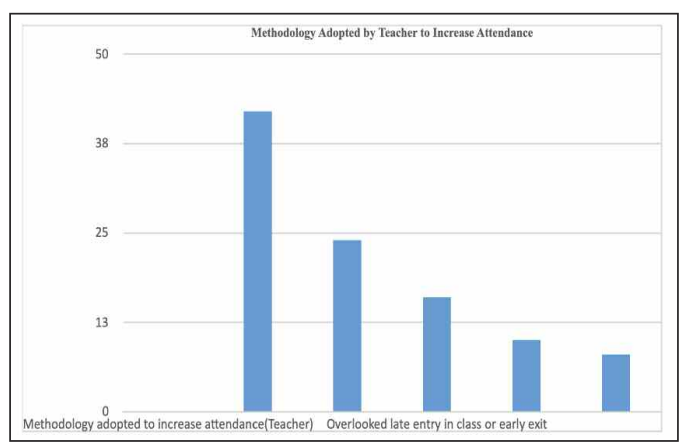

Lastly one extra question was asked from teachers for the methodology they adopted to maintain attendance in class, because at one stage online education becomes very monotonous and attendance of students starts to gradually decrease. $42 \%$ of teachers adopted a very friendly behavior with students so that they do no fear to attend classes; $24 \%$ agreed to giving simple quizzes and assessment sheets to students; followed by $16 \%$ who overlooked factors like timings of entry and exit in class; while $8 \%$ rewarded their students with good attendance in the form of ecertificates,

Additional marks in internal assessment, etc. These findings can be of great help while designing future models of education in such pandemic times.

\section{Conclusion}

As per findings of this survey certain suggestions for policy makers are:

- Separate small study room can be had while designing hostels for students with Internet Connectivity since majority of students did not have a separate room to study.

- $44 \%$ of students used smartphones as they could not afford a laptop, in near future students with good performances can be rewarded with laptops.

Since more students are using smartphones teachers must ensure that all educational apps which they are using for teaching should work on mobile phones also.

- Time duration of lectures be reduced as students complained about bandwidth getting consumed more due to larger duration of lectures.

- Students who cannot afford conveyance charge to college daily for attending classes can be permitted to attend the same via online mode.

- Lab Instructors be given special training to demonstrate practicals and prepare videos of same which can be uploaded on site for students.

- A free webinar can be conducted on regular basis for both teachers and students to update them of new technology and solve their issues related to digital divide.

Findings of this study and the suggestions given on its basis can help develop competencies in both teachers and students and help them face the problem of digital divide, which will help them in smooth conduct of their education in future pandemic times. These findings offer some early indications to policymakers and school leaders that the experience of distance/online teaching and learning, although challenging, may have lasting positive effects, opening up interesting possibilities for innovation and new ways of working, especially if supported by appropriate and timely professional development. 


\section{Acknowledgement}

The authors are thankful to all teachers and students for their participation.

\section{Funding}

This research work did not receive any specific grant from funding agencies in the public, commercial, or not-for-profit sectors.

\section{References}

1. ADITI MADAN, SONALBINDAL, ANIL KUMAR GUPTA (2021) Social distancing as risk reduction strategy during COVID-19 pandemic: A study of Delhi-NCT, India, International Journal of Disaster Risk Reduction, 63(1), 1- 13 doi: 10.1016/j.ijdrr.2021. 102468.

2. AFFOUNEH S, SALHA S N, KHLAIF Z (2020) Designing quality e-learning environments for emergency remote teaching in coronavirus crisis. Interdisciplinary Journal of Virtual Learning in Medical Sciences, 11(2), 1-3.

3. AGRAWAL V, AGRAWAL A, AGARWAL S (2016) Assessment of factors for e-learning: An empiricalinvestigation. Industrial and Commercial Training, 48(8),409-415. https://doi.org/10.1108/ICT-03-2016-0015.

4. AL-FRAIHAT D, JOY M, SINCLAIR J (2020) Evaluating Elearning systems success: An empirical study. Computersin Human Behavior, 102, 67-86. https://doi.org/ 10.1016/j.chb.2019.08.004.

5. ANDREW SKOURDOUMBIS, TREVOR GALE (2013) Classroom teacher effectiveness research: a conceptual critique, British Educational Research Journal, 39(5), 892906. https://doi.org/10.1002/berj.3008.

6. ARINTO P B (2016) Issues and challenges in open and distance e-learning: Perspectives from the Philippines.International Review of Research in Open and Distributed Learning, 17(2), 162-180. https://doi.org/10.19173/irrodl.v17i2.1913

7. BEN HU, HUA GUO et.al (2021) Characteristics of SARS-CoV-2 and COVID-19. Nature Reviews Microbiology, 19, 141-154.

8. CIDRAL W A, OLIVEIRA T, DI FELICE M, APARICIO M (2018) E-learning success determinants: Brazilianempirical study. Computers \& Education, 122, 273-290. https:// doi.org/10.1016/j.compedu.2017.12.001.

9. DOMENICO CUCINOTTA, MAURIZIO VANELLI (2020) WHO declares COVID-19 a pandemic(2020) Acta Biomedica 91(1).157-160 doi:10.23750/abm.v91i1.9397.

10. EILEEN BRIDGES (2017) Technology in Marketing Education: Insights from Sales Training, (2017) International Journal of Educational Technology in Higher Education, 14(25), doi: 10.4018/978-1-4666-4014$6 . \operatorname{ch} 015$

11. FAVALE T, SORO F, TREVISAN M, DRAGO I, MELLIA M (2020) Campus traffic and e-Learning during COVID-19 pandemic. Computer Networks, 176, 107290.

12. ISLAM N, BEER M, SLACK F (2015) Elearning challenges faced by academics in higher education. Journal of Education and Training Studies, 3(5), 102-112.

13. KAPASIA N, PAUL P, ROY A, SAHA J, ZAVERI A, MALLICK R, ... \& CHOUHAN P (2020) Impact of lockdown Teaching Learning on learning status of undergraduate and postgraduate students during COVID-19 pandemic in West Bengal, India. Children and Youth Services Review, 116. https:// doi.org/10.1016/j.childyouth.2020.105194.

14. LOKANATH MISHRA, TUSHAR GUPTA, ABHA SHREE REMUZZI (2020) Online teaching-learning in higher education during lockdown period of COVID-19 pandemic, International Journal of Educational Research Open, 1, 100012. https://doi.org/10. 1016/j.ijedro.2020.100012.

15. LUCA BOTTURI, PETER GOODYEAR et al (2020) Online University Teaching During and After the Covid - 19 Crisis: Refocusing Teacher Presence and Learning Activity Postdigital Science and Education 2. 923-945.

16. SHIVANGI DHAWAN (2020) Online Learning: A Panacea in the Time of COVID-19 Crisis. Journal of Educational Technology Systems , 49(1), 2020. https://doi.org/10. 1177/0047239520934018

17. WAYNE F CASCIO AND RAMIRO MONTEALEGRE (2016) How Technology is Changing Work and Organizations ,Annual Review of Organizational Psychology and Organizational behavior 3, 349-375. https://doi.org/10.1146/annurev-orgpsych- 
041015-062352.

18. PER ENGZELL, ARUN FREY, MARK D VERHAGEN (2020) Learning loss due to school closures during the COVID-19 pandemic, Proceedings of the national Academy of Sciences, America , 118(17), 1-7. https://doi.org/10.1073/pnas.2022376118.

19. MEGAN KUHFELD, JAMES SOLAND, BETH TARASAWA (2020) Projecting the Potential Impact of COVID-19 School Closures on Academic Achievement, Educational Researcher ,49(8), 549- 565. https://doi.org/10.3102/0013189X20965918.

20. OWUSU-FORDJOUR C, KOOMSON C K, HANSON D (2020) The impact of Covid-19 on learning-theperspective of the Ghanaian student. European Journal of Education Studies, 7(3). https://doi.org/10.5281/ zenodo.3753586.

21. MUTHUPRASAD T, AISWARYA S, ADITYA K S, GIRISH K. JHA (2021) Students' perception and preference for online education in India during COVID -19 pandemic, Social Sciences and Humanities Open, 3(1), 1 - 10. https://doi.org/10.1016/ j.ssaho. 2020.100101.

22. TODOROVA N, BJORN-ANDERSEN N (2011) University Learning in Times of Crisis. The role of IT Accounting Education, 20(6), 597- 599. https://doi.org/10.1080/ 09639284.2011 .632913$. 